\title{
Feedback in L2 Writing: The Students' Perspective
}

\author{
GABRIELA VoKIC \\ Dept. of Foreign Languages and Literatures \\ Southern Methodist University, Dallas, TX
}

Received: 1 May 2007 / Accepted: 28 July 2007

ISSN: $1697-7467$

\begin{abstract}
Given the disparate views in L2 writing literature on what constitutes effective teacher feedback, this qualitative study approached this issue from the student's perspective.

In order to examine what constitutes effective teacher feedback from the student's standpoint, fifty-four student responses to three drastically different feedback styles were analyzed.

The results of this preliminary study are partially in line with Hyland (1998), since it was found that whether a particular style of feedback is regarded as effective or not depends on students' individual preferences, their individual differences in needs and student approaches to writing.

Implications for teaching L2 writing are discussed.
\end{abstract}

Key words: L2 writing, teacher feedback, peer feedback, student preferences, pedagogy.

RESUMEN: Dadas las posturas dispares en la literatura existente sobre la escritura en L2 acerca de lo que constituye feedback eficiente, este trabajo cualitativo preliminar investiga el asunto desde el punto de vista del estudiante.

Para examinar qué constituye feedback eficiente desde la perspectiva estudiantil, se han analizado reacciones de cincuentaicuatro estudiantes a tres tipos de feedback drásticamente diferentes.

Los resultados coinciden con Hyland (1998). Se ha concluido que la eficiencia de cierto tipo de feedback depende de las preferencias individuales de los estudiantes, las diferencias en sus necesidades y sus enfoques al proceso de escritura.

También se presentan implicaciones pedagógicas.

Palabras clave: escritura en L2, feedback del instructor, feedback estudiantil, preferencias estudiantiles, pedagogía.

\section{FeEDbaCk IN L2 WRITING: WHAT DO EXPERTS SAY?}

Feedback has been given a lot of attention in second language research and not without reason, since the relative success of second language writers depends directly on the quality and effectiveness of the feedback they are given. Hence, the notion of feedback in second language writing has been approached from various points of view and analyzed along various parameters. Very generally those discussions can be grouped into those concerning whether 
feedback should focus on form or on content, whether it should be explicit or implicit, how helpful and useful it is for the student who wishes to improve his/her writing skills in the target language, as well as what the differences between teacher and peer feedback are. Conflicting views on each of these counts can be encountered in the literature.

\subsection{Feedback on Content vs. Feedback on Form}

Even though the concern with focus on form or focus on content was initially expressed in the area of L2 teaching in general, this concern was transferred to L2 writing as well. In this vein, Zamel (1985) noted that until that point in time teachers were more focused on language-specific errors and she pointed out a need for more content-based feedback (Zamel, 1985: 96). However, Ashwell (2000) finds that feedback on content has only moderate effect on revision, because the students tend to rely heavily on form feedback (Ashwell, 2000: 243).

Additionally, Truscott (1996) argued that grammar correction in L2 writing classes should be abandoned, since it is not only inefficient, but rather harmful (Truscott, 1996: 360). Ferris (1999) strongly disagreed and pointed out that until some specific questions are answered (such as do teachers respond accurately to student errors; are students more able to make progress in monitoring for certain types of errors than others; which student variables affect learners' willingness and ability to benefit from error correction; which methods, techniques, or approaches to error correction lead to short- or long-term student improvement, etc.), grammar correction should not be abandoned, especially since students rely so heavily on it (Ferris, 1999: 9).

\subsection{Explicit vs. Implicit Feedback}

Another issue transferred from L2 instruction in general to the area of L2 writing is how explicit feedback should be. In this vein, Semke (1984) claims that progress in writing is enhanced by written commentaries and questions alone, that corrections do not increase writing accuracy, writing fluency or general language proficiency, as well as that corrections may have a negative effect on students' attitudes especially when students must make corrections by themselves (Semke, 1984: 195).

However, Leki (1991) in a study that investigated students' preferences for feedback concluded that students want and expect their teachers to correct all errors on their written work, because they equate good writing with error-free writing (Leki, 1991: 203).

Additionally, Ferris and Roberts (2001) compared three different feedback conditions: a) errors marked with codes from different error categories, b) errors underlined but not otherwise marked or labeled, and c) no feedback. One of the conclusions reached was that there is no difference in performance between students who received coded and students who received just underlined feedback (Ferris and Roberts, 2001: 176).

Finally, even though Hyland and Hyland (2001) do recognize mitigation strategies as a useful means of minimizing the force of criticisms, they also claim that such indirectness carries a lot of potential for incomprehension and miscommunication (Hyland and Hyland, 2001:207). 


\subsection{Usefulness/Helpfulness of Feedback}

The effectiveness of teacher feedback on improving writing skills in an L2 has also been questioned. Fazio (2001), for instance, found no significant difference in accuracy due to feedback conditions (Fazio, 2001: 245).

However, a conclusion reached by Ferris and Roberts (2001) contradicts this finding. Namely, in their study Ferris and Roberts observed that students who received any kind of feedback (either coded or just underlined) significantly outperformed students who received no feedback at all (Ferris and Roberts, 2001: 176).

\subsection{Teacher vs. Peer Feedback}

The discussions related to the relationship between teacher feedback on the one hand and peer feedback on the other, seem to suggest that revisions made as a result of teacher and peer feedback are more often meaning-level oriented, since students can make surface-level revisions on their own (Paulus, 1999: 283).

It is also suggested that students favor teacher feedback, but peer feedback is valued as well, due to the fact that it enhances a sense of audience, raises learners' awareness of their own weaknesses and strengths, encourages collaborative learning, and fosters the ownership of text (Tsui and $\mathrm{Ng}, 2000$ : 167-168).

\section{FEEDbACK IN L2 WRITING: WHAT DO STUDENTS THINK?}

\subsection{Motivation for This Study}

The motivation to conduct this study has both a theoretical and practical basis. From a theoretical standpoint, it was considered that, given such disparate views in the existent literature on all the afore mentioned parameters concerning feedback in L2 writing, looking into students' perspectives on what constitutes effective feedback in the process of L2 writing could provide further insight on the issue at hand.

Practically, the motivation to conduct this study arose from specific needs of the Spanish as a second language program at the university where the data were collected. Namely, at this institution ${ }^{1}$, students who have completed their second language requirement and who desire to major or minor in Spanish have to take a sequence of two third-year intermediate courses with a focus on writing, SPAN 301 and SPAN 302. A particular trait of these courses is that they consist of alternating two-week periods of Tutorías (Tutorials) and Seminarios (Seminars). There are four tutorial periods and three seminar periods during each semester. The tutorial periods are predominantly grammar-oriented and the students stay with the same instructor throughout the semester for all tutorial periods. On the other hand, seminar periods are heavily culture-oriented and the students can have up to three different seminar instructors in the course of the semester, due to the fact that they can choose the seminars they would like to attend.

\footnotetext{
${ }^{1}$ For more details about this academic institution, see section 2.2.1.
} 
Throughout the semester the students have to write three compositions, one for each seminar period. The students are given the opportunity to write two drafts per each composition: the first draft and the final draft. The first draft is corrected by the seminar instructor. The student is then given the opportunity to revise his/her composition and incorporate the suggestions and corrections provided by the seminar instructor, after which s/he turns in the final draft, which is graded by the tutorial instructor. Although both instructors have to provide feedback on content, grammar, structure and style, the seminar instructor predominantly focuses on content in his/her feedback, whereas the tutorial instructor's comments are more directed toward form.

Hence, due to the structure of SPAN 301 and 302 in this university, in the course of only one semester the students can be exposed to up to four different types of feedback: one from the tutorial instructor and additional three from each seminar instructor. One striking observation for the author of this study was that students not only receive up to four types of feedback, but that the type of feedback differs significantly from one instructor to another. Examples of these significantly different types of feedback are represented in Appendices A, B, and $\mathrm{C}^{2}$. Such variability in providing feedback by the instructors frequently created confusion among the students. As a result, instead of receiving higher grades on final drafts after having incorporated suggestions provided by the first grader, the tendency to score lower on final drafts was observed among the students, which directly contradicts the purpose of providing L2 writers with feedback in the first place.

In conclusion, the question that imposed itself was how the L2 learners at this particular academic institution react to and view these different feedback styles. Thus, the main goal of this preliminary study was to investigate the students' reactions to three drastically different feedback styles and in doing so determining what constitutes effective and helpful feedback from the students' perspective.

\subsection{Methodology}

\subsubsection{Subjects}

The participants in this study were fifty-four native speakers of English, all undergraduate students at a large North American university, who were enrolled in SPAN 302 at the time of data collection. There were forty-two female and fourteen male subjects. They were all from the industrial Midwest area. Their mean age at the time of data collection was 18.7. On average, their L2 instruction had started at the age of 13.2 and they had studied Spanish for an average of 5.9 years. Their proficiency in Spanish ranged from intermediate to intermediate high.

Furthermore, none of the participants were heritage speakers nor have they ever left the United States, either for study abroad, tourism or any other purposes. Finally, all subjects reported no competence in any second language other than Spanish.

\footnotetext{
${ }^{2}$ It should be pointed out that feedback samples in Appendices A, B, and C represent only illustrations of the most extreme types of feedback, and that there are varying degrees in between those extremes. Additionally, all three types of feedback presented here were provided by seminar instructors.
} 
The subjects were informed of the purpose of this study. All participants were volunteers and they were rewarded for completing the survey by elimination of one homework assignment.

\subsubsection{Data Collection}

The participants were presented with a packet consisting of a set of instructions, a questionnaire with open-ended questions and three different feedback samples. In the instructions the students were told to assume that all three compositions were of the same quality, that they had written the compositions in question and to focus on the feedback provided rather than the composition itself. After that, they were asked to express how they would have responded or reacted to each feedback style. More specifically, each feedback sample was preceded by a sheet that asked the participants a) to express whether they find that particular kind of feedback useful and/or helpful overall, b) to identify positive characteristics of that particular kind of feedback (if applicable), and c) to identify negative characteristics of that particular kind of feedback (if applicable).

Additionally, the last page of the packet asked the students to comment on what feature they would like to be included in teacher feedback, as well as to express their opinions on peer feedback.

The choice of feedback samples included in the packet was based on the amount of information and types of comments provided to the student, as well as on the visual presentation of the feedback. As can be seen from Appendices A and B, feedback samples \#1 and \#2, respectively, provide a relatively fair amount of comments on grammar, vocabulary, content, and to a certain extent style and organization, but they do so in different ways: sample \#1 appears to be fairly cluttered and unorganized, whereas the presentation of comments in sample \#2 is relatively more structured and coherent. On the other hand, feedback sample \#3 (Appendix C) hardly contains any comments and they all address surface-level errors.

\subsubsection{Data Analysis}

Data were analyzed qualitatively and with descriptive statistics, where applicable. More specifically, mean values are reported for responses to question \#1, which asked the students to express whether they find that particular kind of feedback useful overall. On the other hand, students' responses to questions \#2 and \#3 (which asked them to identify positive and negative traits of that particular kind of feedback) as well as those that asked about features they would like to be included in the feedback and opinions on peer feedback were analyzed qualitatively and summarized.

\subsubsection{Main Hypothesis}

Based on the afore outlined properties of feedback samples used in this study, the main hypothesis is that feedback samples \#1 and \#3 will be regarded as the least useful and least effective by the students, whereas the feedback sample \#2 approximates the most what effective and helpful feedback should look like. 


\subsection{Responses to Feedback Sample \#1 (Appendix A)}

On average $79 \%$ of the students in this study reported this kind of feedback to be overall useful and/or helpful.

Positive characteristics that were identified in this kind of feedback are summarized below:

a) It summarizes common mistakes at the end of the paper.

b) It explains why changes should be made (e.g. see the instructor's comments on the usage of indefinite articles and false cognates).

c) It has a simple coding system (e.g. S.V. equals subject-verb agreement, G. equals gender).

d) Comments are made on content as well as on form.

However, the students identified certain negative characteristics as well in this feedback sample:

a) This kind of feedback was characterized as cluttered and unstructured, and as such overwhelming and at times frustrating.

b) The occasional use of rhetorical questions (e.g. Why did you use the subjunctive here?; What do you mean by the Matilde?) was regarded as redundant and interpreted as overt criticism by the students.

c) There is very little praise. One student's comment succinctly summarizes the students' need for praise: 'Students like to hear that they are doing a good job and although certain things may be wrong, they are still trying their best.' This eagerness for positive reinforcement can also be illustrated by the fact that the students interpreted the relatively ambiguous comment 'Not bad!' as praise rather than criticism.

d) There is excessive criticism. In this feedback sample extensive usage of exclamation marks, question marks and underlining of particular components of the text, as well as the usage of rhetorical questions (e.g. Why did you use the subjunctive here?; What do you mean by the Matilde?) was interpreted as instances of criticism.

e) Consequently, heavy criticism led to the reading that there is a 'mean and hostile tone' in this kind of feedback.

f) The fact that this kind of feedback visually appears cluttered led the students to express the concern with not knowing where to begin the correction and revision process.

g) Additionally, students thought that corrections and comments are spatially too distant from actual errors, which makes it difficult to identify which particular correction or comment refers to which particular error.

h) Occasional inconsistency in marking was also pointed out.

Additionally, the students also characterized this feedback sample as being very specific. However, depending on the student, this trait was regarded as both positive and negative. The students who viewed being specific as a positive characteristic reported appreciating being told not only what to change, but also how changes should be made. On the other hand, students that regarded being specific as negative reported that this kind of feedback was excessively specific and that they would have preferred it if the instructor had just marked what was wrong and/or needed work, without saying how it should be done. 


\subsection{Responses to Feedback Sample \#2 (Appendix B)}

In responses to feedback \#2, $81 \%$ of the students on average reported this kind of feedback to be overall useful and/or helpful.

Positive characteristics that were identified in this kind of feedback are as follows:

a) It is regarded as concise.

b) It has a clear layout and is thus regarded as orderly.

c) It is consistent in coding.

d) It is specific in that it provides suggestions and/or recommendations for change.

e) The students expressed particular satisfaction with the way clarification requests were made: e.g.

Explain a little bit more... as opposed to What do you mean by this? The first kind of comment is regarded as more polite, whereas the second remark is interpreted as overt criticism, even though both serve the same purpose.

f) Even though there was no explicit positive reinforcement in this type of feedback, it was not regarded as directly discouraging either.

Negative characteristics identified in this type of feedback consisted of the following:

a) Feedback is given in the target language.

b) The way in which the instructor employs arrows in the text is difficult to follow.

c) The students reported that this kind of feedback displayed inconsistent coding because it switched from symbols to words (e.g. the sudden usage of $W V$ (wrong verb) at the end of the composition vs. Pret. vs. Imp. (Preterit vs. Imperfect)).

d) It focuses mainly on surface errors, and hence there is a lack of feedback on content and organization.

e) Lack of praise was observed as well.

\subsection{Responses to Feedback Sample \#3 (Appendix C)}

In the case of feedback sample \#3, $65 \%$ of the students on average reported that this kind of feedback was useful overall. More precisely, the students stated that even though there was very little feedback provided in this sample, the comments that were provided were found to be useful.

Positive characteristics identified in this feedback sample are as follows:

a) It provides actual corrections and in that sense it is direct and specific.

b) There is no hostile or criticizing tone in this kind of feedback.

Negative characteristics identified by the students were as follows:

a) It does not provide enough information and/or feedback. According to the students, the fact that not enough information is included in the feedback sends out two messages: either that the instructor does not care (about the student, the paper, or both) or that the paper is perfect. However, more often than not, the students relate to the first message, which in turn negatively affects their motivation to further work on the composition.

b) It should provide directions for correction rather than actual corrections. Namely, even though the students did report that providing corrections is positive in that it 
requires little effort on the students' side and hence saves time, they also recognized that in this particular case they would have wanted to be involved in the process of revision of their own work, an opportunity which was not granted by the instructor who provided this type of feedback.

c) This feedback does not specify why those particular changes should be made.

d) There is no feedback on content and organization.

e) Even though this kind of feedback was not directly discouraging, it lacked explicit positive reinforcement as well.

f) The students also found that this instructor had poor handwriting.

Notice that the pattern that surfaces again is discrepancy in students' perception of direct and specific feedback, which depending on the student, is viewed as both a positive and negative trait.

\subsection{There Should Be More...}

Finally, the students were asked to comment on what feature they would have liked to see in the feedback provided by their Spanish 301 and 302 instructors that they did not encounter in the types of feedback examined. The most frequently cited characteristics were as follows:

a) There should be more general comments on style. This observation indicates that the students are aware of the fact that relatively successful writing in a second language goes beyond mastery of grammar as well as beyond the sentence-level.

b) There should be more positive reinforcement. Notice that throughout the three feedback samples there is a constant request for more praise. In this vein, one student pointed out: 'If you point out when things are wrong, then also point out when something is really good.'

c) A need for standardized coding was expressed as well, which would eliminate having to decipher instructors' personal notation from one composition to another.

d) The students also expressed the need for help with the process of writing, because, as one student pointed out, 'it is difficult to convert thought into writing.'

\subsection{Peer Feedback}

The last question of the survey asked the students to express their opinions on peer feedback. The students in this study found peer feedback to be generally helpful.

Positive characteristics identified in peer feedback are as follows:

a) Students thought that both parties benefit from this kind of feedback. That is, the student who receives the feedback benefits from the very feedback, whereas the student providing the feedback gets to practice his/her own skills and test his/her own knowledge of L2.

b) The most commonly cited positive characteristic of peer feedback was that comments provided by peers represent kind criticism, due to the fact that peers can relate to the challenges of writing a composition in the L2.

c) In the same vein, since peers can relate to the challenges of writing a composition in the L2, the students found it comforting that they were not the only ones having particular problems.

d) Finally, peer feedback was regarded as easy to understand. 
Negative characteristics identified about peer feedback are as follows:

a) The most frequent criticism peer feedback received was that certain students may benefit more from it than others. More precisely, the students were aware of the fact that depending on the students' level of proficiency in an L2, one party may benefit more than the other.

b) Also, peer feedback is not always specific, as a result of which the student receiving the feedback does not know how to address and/or incorporate the suggestions provided.

\section{Discussion of RESUlts}

In terms of peer feedback, the results of this study are consistent with previous findings, according to which teacher feedback is more highly regarded than peer feedback, but peer feedback is valued as well.

In regard to teacher feedback, the obtained results disprove the main hypothesis, according to which the styles of feedback encountered in sample \#1 and sample \#3 would be regarded as not useful or helpful by the students, whereas the style of feedback displayed in sample \#2 would approximate the most what effective feedback should look like. Moreover, the results indicate that each feedback style was viewed as useful and helpful to a certain extent at least by a certain percentage of students, even though there was a slight preference for feedback styles displayed in samples \#1 and \#2.

These results seem to imply that what constitutes effective feedback in L2 writing depends on students' individual preferences. This implication is drawn from the fact that there were contradictions in students' reports in term of what constitutes positive or negative characteristics of a particular feedback style. For instance, in feedback samples \#1 and \#3 certain students identified being specific as a positive characteristic, whereas other students thought that this kind of feedback was excessively specific, what they viewed as a negative quality. Additionally, the coding system in feedback sample \#2 was regarded as effective by certain students, whereas other students thought it displayed inconsistencies and labeled it as inefficient.

This result, according to which different styles of teacher feedback in L2 writing can be regarded as both efficient and inefficient at the same time, depending on students' personal preferences, finds certain support in the study of Hyland (1998) which investigated reactions to and uses of written feedback. This study concluded that use of teacher written feedback varies due to individual differences in needs and student approaches to writing.

\subsection{Pedagogical Implications}

From the point of view of L2 pedagogy the finding of the present study appears to be quite discouraging, because at first sight no direct benefits can be drawn from it and applied to teaching L2 writing. However, notice that regardless of the type of feedback being examined in this study and regardless of the students' personal preference for one feedback style over another, certain characteristics were recurrently classified as positive, whereas others were consistently pointed out as being negative. Among the subjects in this study, the characteristics that were constantly pointed out as being positive were: specific and direct feedback that tells 
not only what but also how changes should be made by means of suggestions for improvement (as opposed to providing the correct answer), positive reinforcement, comments on content and organization of text as well as on language, and a uniform (or even standardized), consistently applied error coding system. On the other hand, feedback characteristics constantly viewed as negative were various explicit or implicit elements that contribute to the criticizing and hostile tone of the feedback (such as excessive underlining or usage of question and exclamation marks, rhetorical questions or explicit criticism), lack of positive reinforcement, comments on language only, and visually confusing or uninterpretable presentation of the feedback.

\section{Conclusion}

Given the fact that in the existent literature on L2 writing there are disparate views on what constitutes effective and helpful teacher feedback, this preliminary study aimed to approach this issue from the student's perspective.

In order to analyze what constitutes effective and helpful teacher feedback from the student's standpoint, fifty-four student responses to three drastically different feedback styles were gathered and analyzed qualitatively.

Because of the fact that this is a small-scale study it is premature to offer any definite conclusions or generalizations and more research needs to be done in order to do so. However, the results obtained can offer preliminary insight into the type of teacher feedback students prefer to encounter in the process of revising their L2 writing.

The findings of this study coincide to a certain extent with Hyland (1998) in that different kinds or styles of teacher feedback can be regarded as both efficient and inefficient at the same time. More precisely, it has been found that whether a particular style or kind of feedback is regarded as effective or not appears to depend on individual differences, or more precisely, students' individual preferences, their individual differences in needs and student approaches to writing.

Although the finding that effectiveness and helpfulness of teacher feedback in the process of L2 writing depends on individual student preferences has no direct significance for and application in L2 pedagogy, recurring positive and negative characteristics that practitioners and L2 teachers can benefit from were found across feedback styles. In that vein, the subjects consistently identified specific and direct feedback, positive reinforcement, comments on both content and form, and a uniform (or even standardized), consistently applied error coding system as positive characteristics. On the other hand, feedback traits constantly viewed as negative were various explicit or implicit elements that contribute to the criticizing and hostile tone of the feedback, lack of positive reinforcement, comments on language only, and visually confusing or uninterpretable presentation of the feedback. 


\section{REFERENCES}

Ashwell, T. (2000). "Patterns of teacher response to student writing in a multiple draft composition classroom: is content feedback followed by form feedback the best method?", in Journal of Second Language Writing, 9: 227-257.

Fazio, L. (2001). "The effect of corrections and commentaries on the journal writing commentaries on the journal writing accuracy of minority- and majority-language students", in Journal of Second Language Writing, 10: 235-249.

Ferris, D. (1999). "The case for grammar correction in L2 writing classes: A response to Truscott (1996)", in Journal of Second Language Writing, 8: 1-11.

Ferris, D., Pezone S., Tade, C. \& Tinti S. (1997). "Teacher commentary on student writing: descriptions and implications", in Journal of Second Language Writing, 6: 155-182.

Ferris, D. \& Robert B. (2001). "Error feedback in L2 writing classes: How explicit does it need to be?", in Journal of Second Language Writing, 10: 161-184.

Hyland, F. (1998). "The impact of teacher written feedback on individual writers", in Journal of Second Language Writing, 7, 255-286.

Hyland F. \& Hyland K. (2001). "Sugaring the pill: Praise and criticism in written feedback", in Journal of Second Language Writing, 10: 185-212.

Leki, I. (1991). "The preferences of ESL students for error correction in college-level writing classes", in Foreign Language Annals, 24: 203-218.

Paulus, T. (1999). "The effect of peer and teacher feedback on student writing", in Journal of Second Language Writing, 8: 265-289.

Semke, H. (1985). "Effects of the red pen", in Foreign Language Annals, 17: 195-202.

Truscott, J. (1996). "The case against grammar correction in L2 writing classes", in Language Learning, 46: 327-369.

Tsui, A. \& Ng, M. (2000). "Do secondary L2 writers benefit from peer comments?", in Journal of Second Language Writing, 9: 147-170.

Zamel, V. (1985). "Responding to student writing", in TESOL Quarterly, 19: 79-101. 


\section{APPENDIX A}

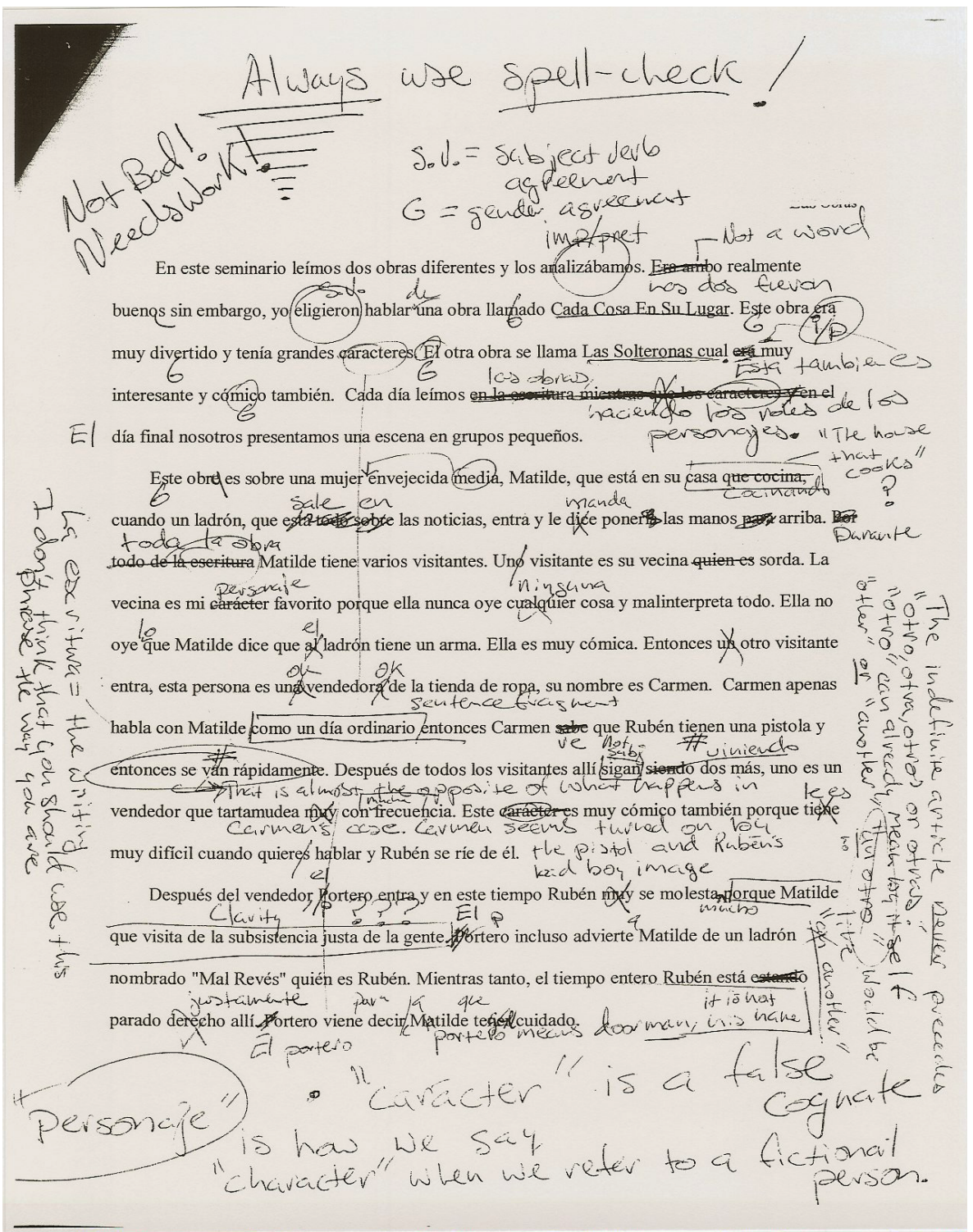


Gabriela Voric

Feedback in L2 Writing: the Student' Perspective

Why have you

ined the subjunctive here?

El argumento es básicamente que el ladrón está intentando robar a esta mujer en su casa, pero extethe go that he caynot rob ella tiene dye muchos visitantes que estén viniendo y el ir ese él no puede robarla con éxito/E1 $\mathrm{h}$ e $\checkmark$ ladrón Matilde casi terminan encima de amigos que se convierten y Rubén apenas consigue molestado con la situación de ocultar del policía, de que éł apenas termina encima de llamarlos sí mismo porque la casa está loca. The thief qud the iMatilde almost euch up on top of fiends that become and rib barely vanages batered with the situation Esta obra tiene un argumento muy bien y tiene grandes caracteres que qunca pensaría en 10 hic Sentevice sfructure froblens quiénes son extremadamente divertidos y agregaría una buena risa al diagrama. Esta obra logra mucho información muy cómico y marca él agradable a leer.

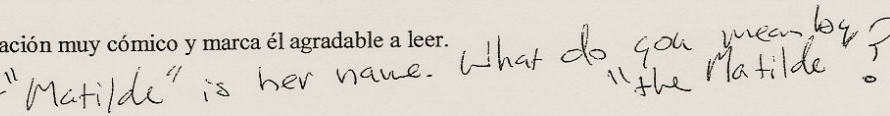

(1)

one very consistent

problem is gender evrors.

Adjectives most always agree in sender and in to this.

(2) Quite often you are woing plava verb torms for singular subjects. Verb torms ending in "in" are always plural

3. Inacuracy d plot goints: (armen cles not run out because sle sees Ruberis gin (4.) Some severe sentence striactwe problen ereas

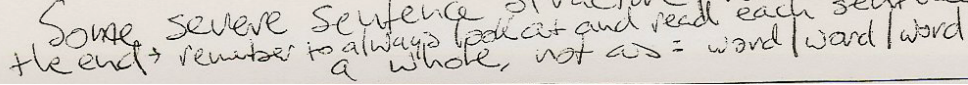

151 


\section{APPENDIX B}

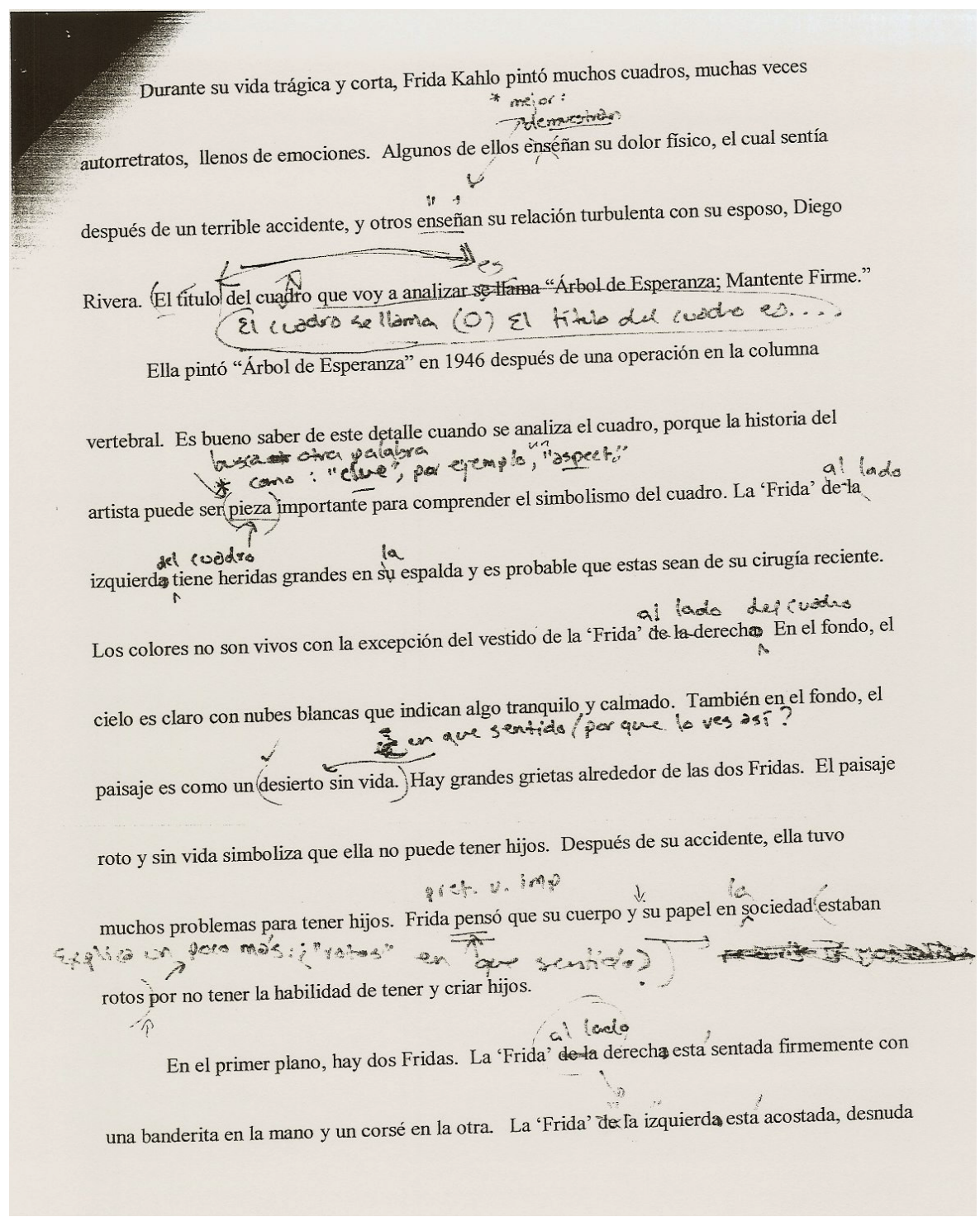




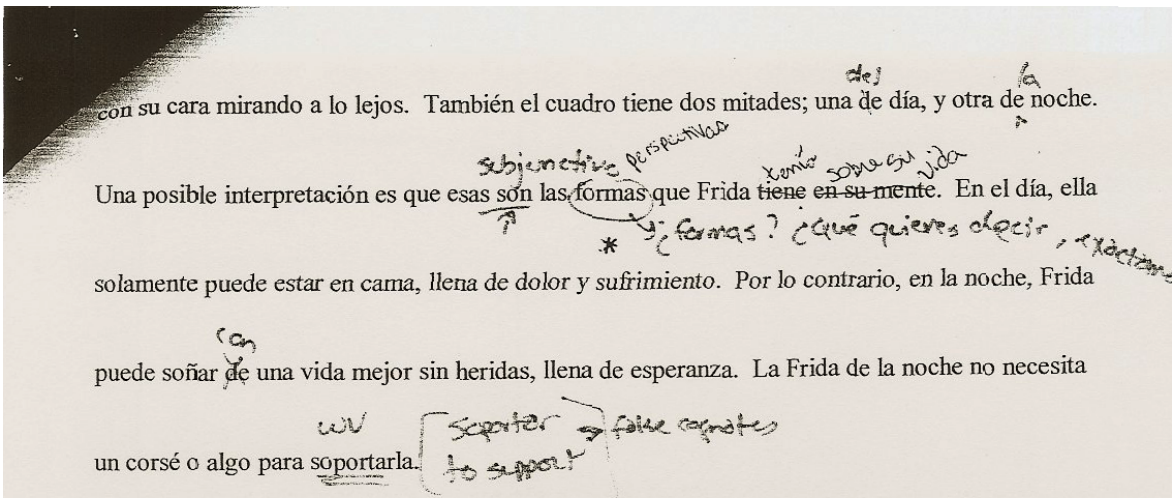

Frida Kahlo tuvo un talento especial para expresar sus pensamientos, sus ideas, suș

esperanzaş, y sus dolorếs. En este cuadro, ella puede expresarse muy bien por el uso de colores,

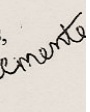

utilizados tanto en el fondo como en el primer plano, y los cuales son-ilustrados-a veces con

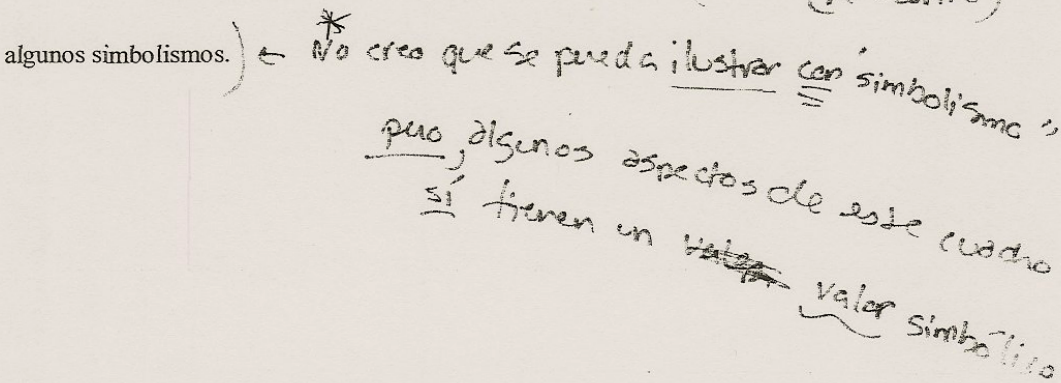




\section{APPENDIX C}

¿Azúcar! Cuando todo el mundo hispano oye esa palabra, ellos saben quien es la

cantante. La cantante es la famosa cubana, Celia Cruz. Celia ha cantado

profesionalmente por más de sesenta años y también ha influido la cultura hispana con su poderosa voz. Nació en La Habana, Cuba alrededor de 1925 en una familia de catorce hijos. Su padre quería que fuera una maestra, pero Celia tuvo otros sueños. Con estos sueños, ganó cinco premios Grammy y el respeto mundial. En su vida, Celia Cruz incluyó muchos de los símbolos que caracterizan su vida e ideales dentro de su música, tuvo un mensaje político sobre el gobierno de Cuba, y desarrolló su voz y sus gustos con experiencia.

A Celia le gustaba incluir muchas frases y palabras auténticas en sus canciones. La primera que ya he mencionado, es la palabra 'azúcar.' La usó mucho en sus canciones probablemente porque es bien sabido que Cuba produce muy buen azúcar y ella estaba

reo iectiocida. 'dulce como el melao', un buen ejemplo de un cubanismo. Esta frase significa algo muy dulce, por ejemplo, si estas hablando de una mujer, ella es extremamente buena y amigable. Es obvio con las dos frases, 'azucar' y 'dulce como melao', que a ella le gusta incluir palabras muy positivas relacionadas al azúcar.

Celia Cruz no cantaba solo sobre cosas ricas, sino que también cantaba sobre actividades políticas. En los años tempranos de 1960, salió de Cuba a México porque no le gustaba lo que estaba ocurriendo en su país, la Revolución Cubana. En su canción "Sobrevivir", sus sentimientos son evidentes. Ella dice "yo me fui buscando para el cielo de la libertad... [pero no voy a olvidar nada o nadie de mi hogar.]" También en esta canción, mencionó que regresará cuando el gobierno fuera diferente. Debido a sus 
sentimientos políticos, el gobierno de Casto prohibió a los ciudadanos cubanos escuchar sus canciones.

Durante sus años como "La Reina de Salsa", su voz, sus tipos de música, y su estilo han cambiado y han desarrollado. Al principio de su carrera, los vestidos de Celia eran conservadores y apropiados. Ella cantó canciones románticas, como una de las primeras, "Melao de Caña." El ritmo era mas lento como una balada y su voz no era todavía tan madura. Después de salir de Cuba, la ropa de Celia fue cambiando. No continuó siendo tan conservadora y empezó a expresar sus gustos y sentimientos por los colores. Sus canciones mantuvieron el aspecto afrocaribeño, pero agregó un ritmo más rápido. Después de más años en los Estados Unidos, sus vestidos brillantes fueron-siendo más populares. Ella es reconocida por pelucas de todos los colores, vestidos de varias

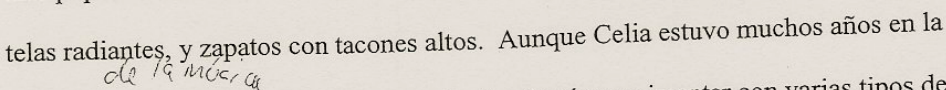
industria, su voz nunca cambió para mal. Continuó experimentar con varias tipos de música como el cha-cha-cha, rumba, son, jazz, salsa, pop latino, y muchas veces, una combinación única del todo.

Hasta el día que Celia Cruz falleció, estaba llena de vida y alegría. En una entrevista, ella dijo que incluso cuando tiene un dolor de cabeza, pero tiene que cantarle a su gente, siempre empieza a sentirse mejor. Desde unos de sus últimas canciones, "Ríe y Llora" hay un frase que resume su vida. "Ríe, llora...esta negrita no pasa de moda," es muy apropiado porque es cierto que ella nunca pasará de moda en los corazones de sus admiradores. 